\title{
漢字書字困難览における方法別の書字訓練効果
}

一単語属性条件を統制した単語群を用いた検討——

\begin{tabular}{|c|c|c|}
\hline 昭江 ${ }^{1)}$ & 彰3,4) & 川崎 \\
\hline 田口 智子6) & 春原＼cjkstart則子4,7) & 福島 \\
\hline
\end{tabular}

要 約：漢字書字に困難を示した 8 歳の右利き男児に関する症例報告である。この児童に対 して漢字の成り立ちを音声言語化して覚える方法 (聴覚法) と書き写しながら覚える従来の学 習方法 (視覚法) の 2 種類の訓練方法の有効性について, 刺激単語に関する属性を統制した単 語群を用いて単一事例実験計画法にて検討した。単語属性に関しては，学年配当以外の表記妥 当性, 親密度, 心像性, 画数の各条件を統制した。 その結果, 聴覚法が視覚法に比べて正答率 と維持率に関して有意に高い結果であった。

さらに属性を統制した単語群において方法別効果の差が認められたこと, および各単語間の 属性による正答率の差は有意ではなかったことから, 今回の結果には, 単語属性による影響を 排除しても訓練法の違いによる影響が大きいと考えられた。

牽引用語：漢字書字困難, 単語属性, 訓練効果, 単一事例実験計画法

\section{Training Effectiveness of Various Therapy Methods in a Child with Kanji Writing Difficulty — An Investigation Using Controlled Word Stimuli by Attributes_-}

\author{
Akie Fujiyoshi' ${ }^{1)}$, Akira Uno ${ }^{3,4)}$, Akihiro Kawasaki ${ }^{5}$, Tomoko Taguchi ${ }^{6)}$, Noriko Haruhara ${ }^{4,7)}$ \\ and Kunihiro Fukushima ${ }^{2}$
}

岡山大学病院耳鼻咽喉科言語聴覚外来 ${ }^{1)}$, 岡山大学大学院医歯薬学総合研究科耳鼻咽喉 - 頭頸部外科 ${ }^{2)}:$ T $700-8558$ 岡山市北区鹿 田町 $2-5-1$

筑波大学大学院人間総合科学研究科 ${ }^{3)}$ : $7305-8577$ 茨城県つくば市天王台 1-1-1

LD ・ Dyslexia センター4) : テ272-0033 千葉県市川市市川南 3-1-1-315

富山大学人間発達科学部 ${ }^{5)}:$ T 930-8555 富山県富山市五福 3190

財団法人テクノエイド協会 ${ }^{6)}$ : †162-0823 東京都新宿区神楽河岸 1-1

目白大学保健医療学部 ${ }^{7)}$ : †339-8501 さいたま市岩槻区浮谷 320

${ }^{1)}$ Division of Speech-Language Pathology and Audiology, Department of Otolaryngology, Okayama University Hospital, ${ }^{2}$ Department of Otolaryngology-Head \& Neck Surgery, Okayama University Graduate School of Medicine, Dentistry and Pharmaceutical Sciences: 2-5-1, Shikata, Kita-ku, Okayama-shi, Okayama 700-8558, Japan

${ }^{3}$ University of Tsukuba, Graduate School of Comprehensive Human Sciences: 1-1-1 Tennodai, Tsukuba, Ibaraki 305-8577, Japan ${ }^{4)}$ LD/Dyslexia Centre: 3-1-1-315, Ichikawa-minami, Ichikawa, Chiba 272-0033, Japan

${ }^{5}$ Faculty of Human Development, University of Toyama: 3190, Gofuku, Toyama-shi, Toyama 930-8555, Japan

${ }^{6}$ Association for Technical Aids: 1-1 Kagurakaigan, Shinjuku-ku, Tokyo 162-0823, Japan

${ }^{7}$ Department of Speech Language and Hearing Therapy, Faculty of Health Sciences, Mejiro University: 320, Ukiya, Iwatsuki-ku, Saitama-shi, Saitama 339-8501, Japan

2009 年 5 月 7 日受稿 2009 年 7 月 9 日受理 
Abstract: The participant was an eight-year-old right-handed boy with Kanji writing difficulty. We investigated the efficacy of two kinds of therapy methods using the single subject design method. Stimuli controlled by word attributes -for example, word validity, imageability, familiarity and number of strokes- were divided into three groups to enable comparison: two training word groups and one non-training group. The results showed that the newly developed method of memorizing the composition of Kanji characters orally (auditory method) is more effective than the traditional learning method (visual method) from the viewpoint of number of correct answers and retention rate. We conjectured that the training effectiveness was greater than for the word attribute method because there was no significant relationship between word attributes and the number of correct answers.

Key words: Kanji writing disorder, word attributes, training effectiveness, single subject design method

\section{はじめに}

発達性読み書き障害の書字訓練の効果について海外 では, Brunsdon ${ }^{1,2)}$, Kohnen ${ }^{3)} ら に よ り ， 1$ 症例に関 して認知神経心理学的な検討がなされている.しかし， 書字訓練法の有効性や介入方法による比較検討を行っ ている報告はほとんどない，また，発達性読み書き障 害児の書字の困難さに対して，障害メカニズムに関す る認知神経心理学的検討やその認知特性に対応した訓 練法の検討も必ずしも十分なされているとはいえな い. 一方, 日本語話者の発達性読及書き障害児に対す る訓練効果や特定の訓練方法の有効性については, 宇

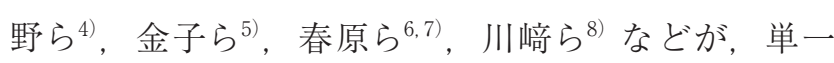
事例実験計画法を用いて定量的な検討を行っている. このうち宇野ら ${ }^{4)}$, 春原 ${ }^{6,7)}$ の報告では，異なる介入 方法が比較検討されている。しかし，これまで訓練刺 激である漢字については比較すべき単語群に関しての 画数や文字数は統制されてはいても, その特徵, すな わち単語属性に基づいた漢字訓練語群や非訓練語群の 統制を行った報告はなく，単語属性によって効果に差 が認められた可能性については検討されていない，そ こで本研究では, 学年配当以外の単語属性すなわち, 表記妥当性, 親密度, 心像性, 画数の各条件が各群で 同等になるよう統制して訓練語群, 非訓練語群を作成 した。 そのうえで, 単一事例実験計画法を用いて, 通 常の写字中心の訓練方法である視覚法と, 良好な認知 機能を活用するバイパス法の一つである聴覚法の $2 つ$ の介入方法による訓練効果を比較検討した。

\section{対象}

\section{1. 症例}

本訓練開始時, 小学校通常学級 2 年次在籍の右利き
男児である，本症例は小学校入学前から，ひらがなの 模写において顕著な困難を伴っていた。図形の模写に おいても同様であり, 一つひとつの模写対象の形態は あるものの全体のまとまりに兵しい印象を有する図形 を描いていた，本児童自身が漢字書字に関して苦手意 識を有しており，なんとか克服したいと強い意思を有 していた。

医学的診断名：発達性読み書き障害

理学所見および神経学的所見 : 特記すべき事項は認 めなかった。

頭部 MRI 所見（フレアー法）：図 $1 \mathrm{a}$ に示す本症例 の頭部 MRI 画像から右側脳室後角の拡大掞よび両側 脳室後角深部白質の石灰化を認めた。

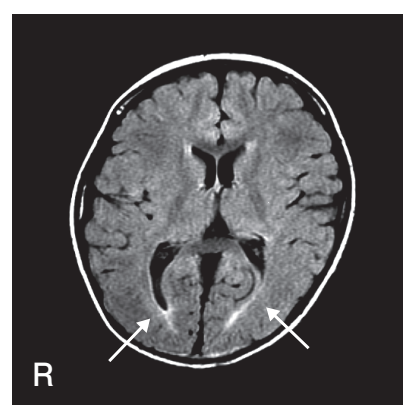

$\mathrm{a} ：$ MRI（フレアー法）

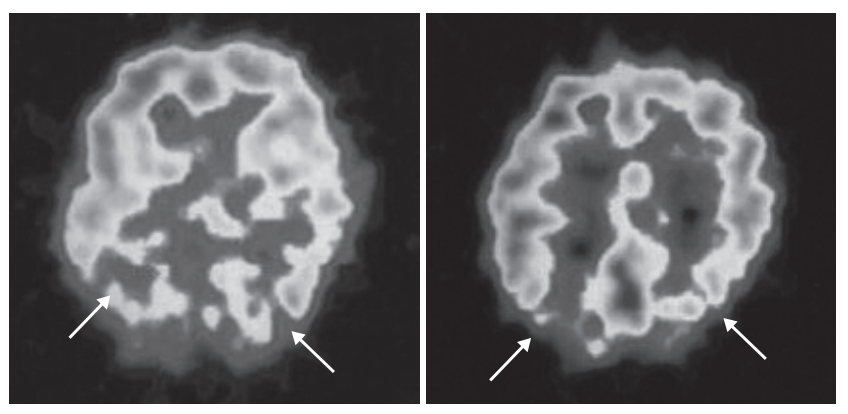

b : SPECT

図 1 本症例における脳画像 (CA6: 2) 
表 1 神経心理学的検査のまとめ



（）内は学年平均值と標準偏差, WISC：日本版 Wechsler Intelligence Scale for Children-Third Edition, ROCFT : Rey-Osterrieth Complex Figure Test, RAVLT : Rey's Auditory Verbal Learnig Test, S-S 法 : 国リハ式 $<$ S-S 法>言語発達遅滞検査, PVT：Picture Vocabulary Test, RCPM : Rey-Osterrieth Complex Figure Test, K-ABC : Kaufman Assessment Battery for Children, STRAW : Screening Test of Reading and Writing for Japanese Primary School Children

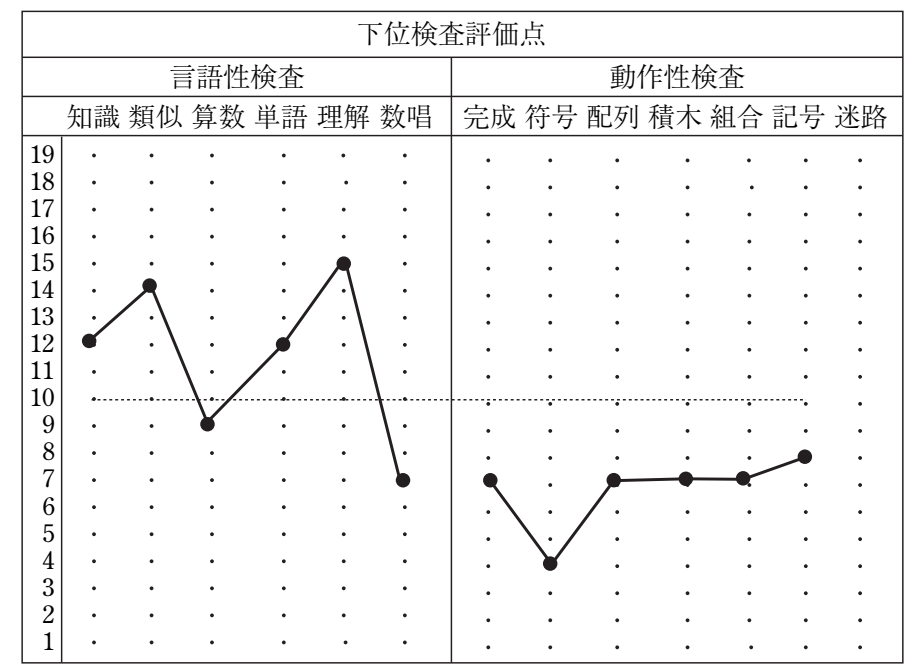

図 2 WISC-III結果（CA6: 6)

脳SPECT 所見：図 $1 \mathrm{~b}$ に示す本症例の脳SPECT 画像から両側の下頭頂小葉から側頭葉にかけての局所 脳血流量の低下を認めた。

発達歴：乳幼児期から幼児期にかけての初期発達に 異常は認められなかった。

本症例の神経心理学的検査所見は，表 1 に示すとお りである。

全般的知的機能 : 図 2 に示すウェクスラー式知能検 査日本版（WISC-III）では，全 IQ 96（言語性 IQ 115,
動作性 IQ 75）であった。レーヴン色彩マトリックス (RCPM) では26/36であった。図 3 に示す $\mathrm{K}-\mathrm{ABC}$ 心理・教育アセスメントバッテリー（K-ABC）では, 標準得点が継次処理尺度 $92 \pm 9$, 同時処理尺度 $100 \pm 8$, 認知処理尺度 $94 \pm 7$, 習得度尺度 $102 \pm 8$ (90\%信頼水 準)であった。

言語機能：国リハ式 $<$ S-S 法 $>$ 言語発達遅滞検査で は, 記号形式一指示内容関係＜段階 5-2>であった。 絵画語い検査 $(\mathrm{PVT})$ では語い年齢が 6 歳 2 カ月であっ 


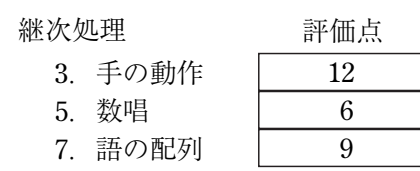

同時処理
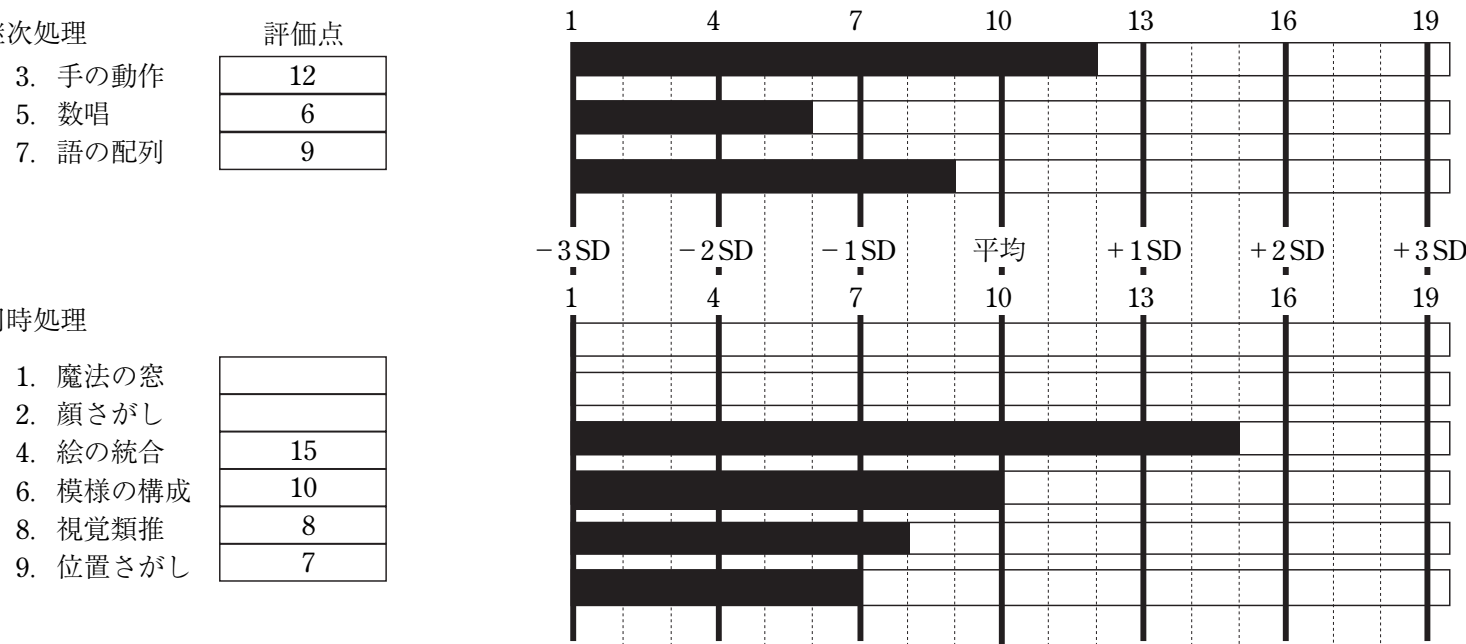

習得度
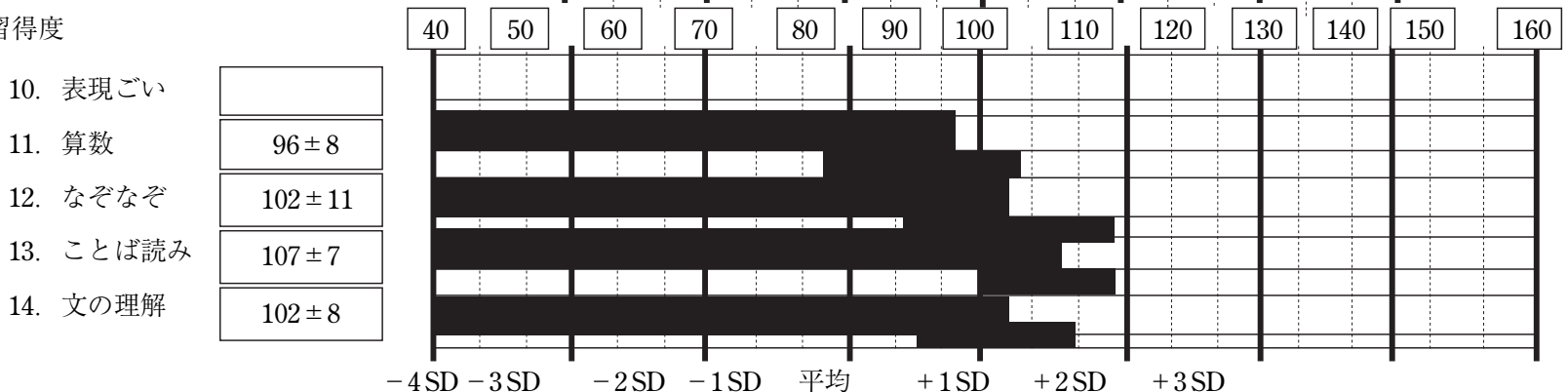

図 $3 \mathrm{~K}-\mathrm{ABC}$ 得点プロフィール（CA8:1）

た。

聴覚情報処理機能：音韻認識課題としての単語逆唱 検査では，3 モーラ語において正答数は $5 / 10,4$ モー ラ語では正答できた課題はなかった. Rey’s Auditory Verbal Learning Test（RAVLT）では, 30 分後の遅 延再生語数 15/15 であった。

視覚情報処理機能: Rey-Osterrieth Complex Figure Test (ROCFT) では, 遅延再生 2/36であった。

学習到達度：小学校 2 年生時における小学生の読み 書きスクリーニング検査 (STRAW) では， -1 標準 偏差より低い正答数を示すものはなかった。

\section{2. 方法}

本症例は就学半年前に大学病院において, 発達性読 み書き障害の可能性が指摘された。要素的認知機能と しては，音韻情報処理過程と視覚情報処理過程双方の 機能低下が疑われたため，今後の漢字に関する習得法 の指針を得るべく単一事例実験計画法を用いて検討を 行った。本研究の目的と訓練計画について詳細な説明 を行い，本人と保護者の了承を得たうえで実施した。

訓練開始時の小学生の読み書きスクリーニング検 査 ${ }^{9)}$ において, 読み書きの習得度が同年歯令平均の -1 標準偏差以内の正答を示していたこと，漢字習得に関 して本対象児が苦手感をもっていながら学習意欲が強
表 2 各群の単語属性值と平均值

\begin{tabular}{ccccc}
\hline $\begin{array}{c}\text { 単語属性 } \\
\text { 属性值 }\end{array}$ & 表記妥当性 & 親密度 & 心像性 & 画数 \\
\hline 第 1 訓練語群 & & & & \\
属性值 & $4.9 \sim 5.0$ & $6.0 \sim 6.6$ & $4.1 \sim 5.5$ & $4 \sim 16$ \\
$\quad$ 平均值 & 5.0 & 6.1 & 4.8 & 10.0 \\
第 2 訓練語群 & & & & \\
属性值 & $4.7 \sim 5.0$ & $5.0 \sim 6.4$ & $3.8 \sim 6.2$ & $4 \sim 16$ \\
$\quad$ 平均值 & 4.9 & 6.0 & 4.9 & 9.5 \\
非訓練語群 & & & & \\
属性值 & $2.8 \sim 5.0$ & $5.1 \sim 6.4$ & $4.0 \sim 6.0$ & $6 \sim 16$ \\
平均值 & 4.8 & 6.0 & 5.0 & 10.6 \\
\hline
\end{tabular}

かったこと，未習得の漢字を用いたほうが訓練法の明 確な比較が可能であることなどの理由により，訓練語 には小学 3 年生で学習する予定の漢字単語を無作為に 抽出した。当該単語の聴覚的理解が可能であることを 確認したうえで，音読と書字が 3 回連続して正答でき なかった漢字単語 45 語を選択した。選択した 45 語を 表記妥当性，親密度，心像性，画数に有意差が出ない ように 3 群に分けた。 2 群を第 1 訓練語群，第 2 訓練 語群，1群を非訓練語群とした。それぞれの群の単語 属性は，表 2 に示すとおりである。

第 1 訓練語群の各属性の平均值は, 表記妥当性 5.0, 
親密度 6.1 , 心像性 4.8, 画数 10.0. 第 2 訓練語群では, 表記妥当性 4.9 , 親密度 6.0 , 心像性 4.9 , 画数 9.5. 非 訓練語群では, 表記妥当性 4.8, 親密度 6.0 , 心像性 5.0, 画数 10.6 であった.

訓練は, 音読しながら写し書きをする視覚法と漢字 の構成要素を音声言語化する聴覚法7.8) の 2 種の方法 にて行った，聴覚法とは，たとえば「化」は，「化け るときはイヒイヒと笑う」というょうに, 漢字の形態 を構成要素に分解して音声言語化して覚える方法であ る.

訓練は 2006 年 7 月の 1 力月間 (前半) と, 11 月の 1 力 月間 (後半) 実施した. 2 カ月の間に当院にて 4 回, 家庭にて 24 回, 合計 28 回の訓練を実施した。来院時 の訓練は週 1 回, 約 40 分とし, 前回来院時以降の訓 練結果と訓練方法 (手続き) の確認を行った。聴覚法 では, 本児と相談して漢字の構成要素を音声言語化し, リング付の単語カードに音声言語化した覚え方を記載 した，家庭学習場面では母親とともに，単語カードを 基に来院時に決めた覚え方で, 音声言語にて記憶し口 頭で表出した後, 覚え方に沿って書字してもらった.

訓練デザインは単一事例実験計画法に基づき, 春原 らの既報7)に従って条件交代デザインを一部改編し て用いた。 ベースラインを A 期, 視覚法による介入 期を $\mathrm{B}$ 期，聴覚法による介入期を $\mathrm{C}$ 期とした.

第 1 訓練語群は $\mathrm{A}$ 期 $-\mathrm{B}$ 期 $-\mathrm{B}$ 除去期（訓練を行わな い期間 $)-C$ 期 $-\mathrm{C}$ 除去期 (訓練を行わない期間) とした。 第 2 訓練語群は $\mathrm{A}$ 期 $-\mathrm{C}$ 期 $-\mathrm{C}$ 除去期（訓練を行わない 期間）とした。第 2 訓練語群の $\mathrm{C}$ 期は, 第 1 訓練語 群の B 除去期から開始し, 同一期間に第 1 訓練語群 と第 2 訓練語群の書字訓練が重ならないように配慮し た。非訓練語群については訓練開始時と終了時に書取 を実施した。訓練効果の解析には McNemer 検定を用 いた。

\section{結果}

第 1 訓練語群では, 視覚法を用いた 1 週間の訓練 $(\mathrm{B}$ 期）の結果, 正答数は $1 / 15$ であった。 その 2 週間後 の検査では正答できた単語はなかった。視覚法訓練 1 週後より開始した聴覚法での 1 週間の訓練（C 期）の 結果, 正答数は $13 / 15$ であった。 その後追跡し正答数 の維持を検討したところ，2 週間後の正答数は $3 / 15$, 3 週間後の正答数は $0 / 15$ と正答数が低下した。この 際の本児の漢字想起方略は, 漢字の構成要素を音声言 語化して思い出す方法ではなく，「どんな形だったか な」などの発言があり,対象の漢字がどのような形だっ
たか思い出そうとしている様子が見られた。

第 2 訓練語群では, 聴覚法を用いた 1 週間の訓練 $(C$ 期）の結果, 正答数は $15 / 15(z=3.62, \quad \mathrm{p}<0.01)$ と すべて書字可能となった. B 除去期の後 (2 週間後) の正答数は $13 / 15(z=3.33, \mathrm{p}<0.01)$ であった. さ らに, 1 力月後の正答数は $13 / 15(z=3.33, p<0.01)$, 3 力月後の正答数は $13 / 15(z=3.33, p<0.01)$ であり, 8 力月後の正答数も $11 / 15(z=3.02, \mathrm{p}<0.01)$ であっ た。

第 1 訓練語群については前半の訓練の後, 再度聴覚 法にて 1 週間の訓練を実施した。 その結果 1 週間後の 正答数は 14/15（ベースライン期との比較 $z=3.47, \mathrm{p}$ $<0.01$, 視覚法との比較 $z=3.33, p<0.01 ）$ と上昇した. 1 力月後の正答数は 13/15 (ベースライン期との比較 $z=3.33, \mathrm{p}<0.01$, 視覚法との比較 $z=2.94, \mathrm{p}<0.01)$, 3 力月後の正答数は 13/15 (ベースライン期との比較 $z=3.33, p<0.01$, 視覚法との比較 $z=2.94, p<0.01)$, 5 カ月後の正答数は $12 / 15$ (ベースライン期との比較 $z=3.18, p<0.01$, 視覚法との比較 $z=2.77, p<0.01$ ) であった，このときの本児は，漢字の形を思い出す方 法ではなく, 聴覚法で覚えた構成要素を口頭で唱える 方法で書字していた。非訓練語については今回の訓練 前後では書字可能となったものはなかった.

正答した漢字と誤答した漢字の表記妥当性, 親密度, 心像性, 画数の各単語属性について, 各群においてマ ンホイットニーのU 検定により検討した。第 1 訓練 語群, 第 2 訓練語群ともに表記妥当性, 親密度, 心像 性, 画数の各単語属性に関して有意差は認められな かった $(\mathrm{p}>0.05)$.

\section{考察}

\section{1. 単語属性が訓練効果に与える影響について}

本研究では表記妥当性, 親密度, 心像性, 画数の各 単語属性を統制して訓練語群 2 群, 非訓練語群を作成 して 2 種類の訓練方法を比較した。 その結果, 聴覚法 では視覚法に比べ有意に正答数が多く, 非訓練語群と 比較して有意に正答率が上昇した。また 1 週間という 短期間にて正答率が上昇したこと，かつ数力月後も正 答率を維持していたことなどから，視覚法に比べて聴 覚法の有用性が確認された。

本研究では, 使用された単語群間での表記妥当性, 親密度, 心像性, 画数に関する単語属性值に差が認め られないように統制した，その結果，方法別効果の差 が認められたこと, および視覚法, 聴覚法それぞれの 訓練によって正答した単語と誤答した単語の間に各属 


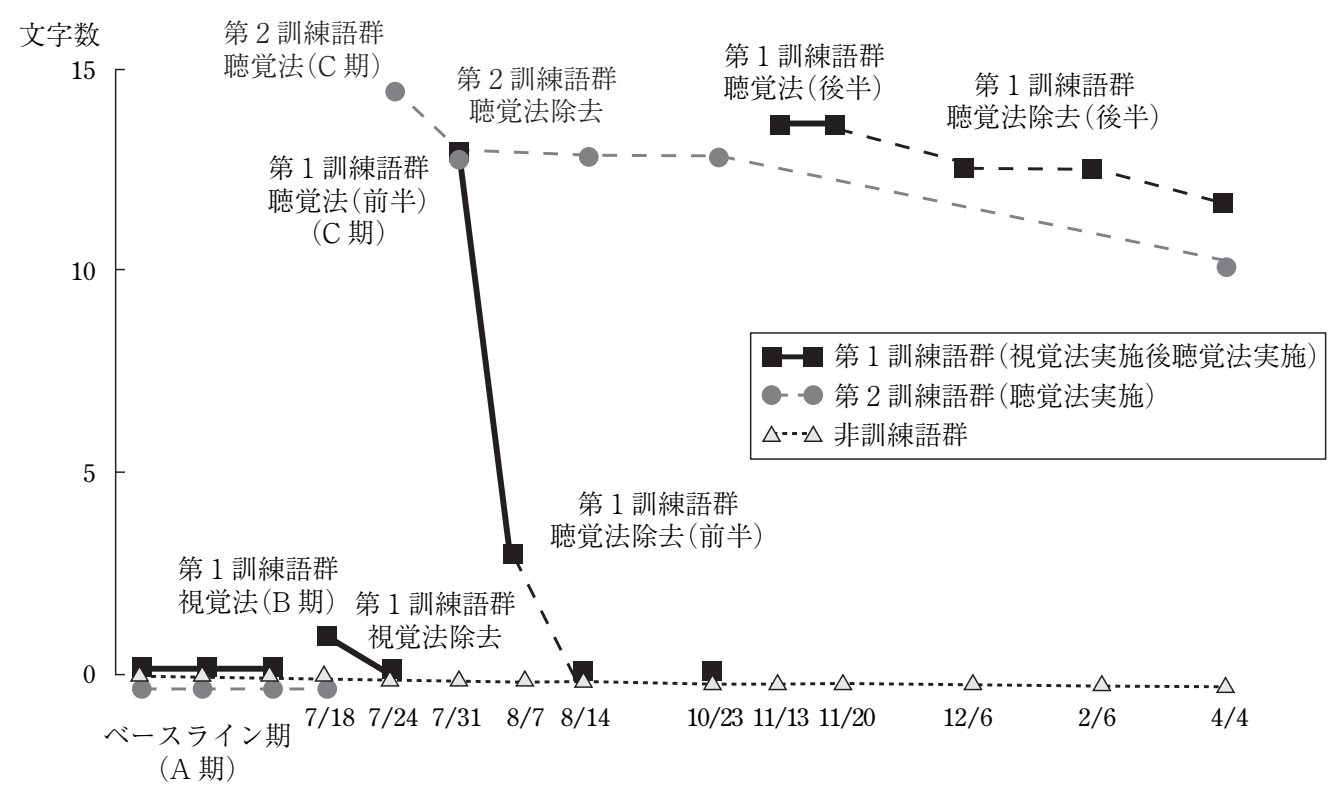

図 4 漢字書字訓練の結果

性において有意差がなかったことから，本児で見られ た訓練効果は，単語属性による影響よりも訓練法の違 いによる結果と考えられた。本研究では，どの単語属 性が訓練効果に寄与するのかという点については目的 としていなかったため実験デザインにも反映させな かった。 今後の課題と思われる。

\section{2. 訓練法の適用について}

本坚童自身が漢字書字に関して苦手意識を有してお り，何とか克服したいと強い意思を有していた点. WISC-IIIの数唱と K-ABC の数唱の得点は低く聴覚的 短期記憶は良好ではないが, RAVLTでの遅延再生数 が示す音声言語の長期記憶は良好に保たれており，聴 覚法が有効と考えられる症例についての先行研究の知 見と合致していた点 ${ }^{4-8)}$. また全般的知能発達につい ても WISC-III RCPM の結果から正常域であった点. 以上の 3 点から春原ら ${ }^{7)}$ の報告どおり, 聴覚法を訓練 方法として用いることが有用ではないかと考えられた 症例であった。発達性読み書き障害児の訓練効果に対 する聴覚法の有効性の報告は認知神経心理学的見地か ら多くなされているが4-8), 今回単一事例実験計画法 に基ついて単語属性を統制した単語に関して方法別訓 練効果を検証した結果においても聴覚法が視覚法に比 ベて有意に訓練効果が認められたことから，視覚情報 処理能力に比して音声言語の長期記憶が優れている児 にとっては聴覚法が学習方略として優れていることが 示されたのではないかと考えられた.

\section{3 . 症例の障害構造と改善のメカニズム}

日本語圈で発達性読み書き障害の背景となる認知障
害としては，音韻情報処理障害に起因する夕イ プ10-12)，視覚認知障害に起因するタイプ，視覚性記憶 障害に起因するタイプ，以上の 2 つを含む視覚情報処 理過程の障害に起因するタイプ, 視覚情報処理障害と 音韻情報処理障害を合併するタイプ13)，および視覚情 報処理障害と音韻情報処理障害に加えて RAN 課題で の処理速度の遅さの三重障害タイプ14) などがある. 本症例には RAN 検査は実施していないが，前述のと おり，視覚認知障害と視覚性記憶障害を認め，また小 学校入学後に実施した音韻認識処理課題の結果も不良 であったことから，少なくとも視覚情報処理過程と音 韻情報処理過程の双方に問題を呈していたと考えられ た。これらの認知機能障害が，本児の書字困難の背景 として考えられる。

本症例は，画像所見において 1$)$ 頭部 MRIにて右 側脳室後角拡大および両側脳室後角深部白質から後頭 葉内側面にかけての石灰化が認められ，2）脳 SPECT 所見において両側の下頭頂小葉から側頭葉に かけての局所脳血流量の低下を認めた。本症例では両 側に所見を認めたが，このうち左側に関しては視覚情 報処理障害と音韻情報処理障害双方に起因する読み書 き障害児の大脳機能低下部位とも同様の部位 ${ }^{13)}$ であっ た. 大脳後方部位や左側頭頭頂葉領域は, 発達性読み 書き障害の重要な機能障害部位と考えられている ${ }^{15)}$. 大脳後方部位は視覚情報処理過程の重要な中枢であ り，左側頭頭頂葉の縁上回は音韻情報処理にかかわる 重要な役割を担っている部位であると考えられている ことから 16-18), 本症例の障害構造として想定した視覚 
情報処理過程と音韻情報処理過程双方の障害説を画像 所見も支持していると思われた.

文字を覚えて書くためには，1）対象の文字を視覚 的に捉えて形態を認知し，2）捉えた形を保持，3） 書くべき文字を想起し再生する過程が必要であると思 われる。本例において, 聴覚法が視覚法よりも訓練効 果を認め, 除去期以降も訓練効果を維持できた背景に は, 視覚情報処理過程に問題のある児にとって音声言 語化したフレーズを覚えることが1）2）をバイパス させ文字形態の想起再生の手掛かりとして有効に機能 したのではないかと思われる。

\section{4. 訓練方法の選択による書字の成績について}

視覚法で学習した後に聴覚法で漢字の書字学習をし た場合，本児は聴覚法による漢字の覚え方で書字しょ うとするのではなく, 聴覚法の前に学習した視覚法に よる漢字の覚え方で漢字を書字しょうとする様子が観 察された。一方, 最初から聴覚法によって学習した場 合には, 漢字の構成要素を音声言語化して書字する様 子が観察された。これらは，1）発達期において, 通 常の学習方略ではなく, 異なる方略を再構築すること には多くの労力を伴う可能性や，2）一度定着した学 習方略が異なる学習方略を習得する際の妨害要因とな りうる可能性, などが考えられ, 最初から適切な訓練 方法を選択することの重要性が示唆されているように 思われる。

成人の記憶障害例における学習においては, 試行錯 誤させる学習よりも, 初めから正答を教示する学習条 件のほうが効果的とされている ${ }^{19)}$. 読み書きに困難を 示す児童に関しても，適切でない方法で反復学習をす ることは学習効果が十分に得られないと考えられた。

以上より, 症例の認知特性を把握することによって, 初めから良好な認知機能を生かした学習方法を選択す ることが重要であると考えられた。

\section{文献}

1) Brunsdon R, Coltheart M and Nickels L: Treatment of irregular word spelling in developmental surface dysgraphia. Cognitive Neuropsychology, 22(2): 213-251, 2005.

2) Brunsdon R, Coltheart M and Nickels L: Severe deveropmental letter-processing impairment: A treatment case study. Cognitive Neuropsychology, 23(6): 795-821, 2006.

3) Kohnen S, Nickels L, Coltheart M, et al: Predicting generalization in the training of irregular-word spelling: Treating lexical spelling deficits in child. Cognitive
Neuropsychology, 25(3): 343-375, 2008.

4）宇野 彰, 金子真人, 春原則子：学習障害児の英単語書き 取りにおける実験的訓練効果. 音声言語医学, 39 : 210214, 1998.

5）金子真人, 宇野 彰, 春原則子, 他：仮名と漢字に特異的 な読み書き障害を呈した学習障害児の仮名書字訓練. 音声 言語医学, 39：274-278, 1998.

6) 春原則子, 宇野 彰, 金子真人, 他: 言語性記憶障害と視 覚的認知障害を認めた小児の 1 例における英単語の書字訓 練. 音声言語医学, $43: 290-294,2002$.

7）春原則子, 宇野 彰, 金子真人：発達性読み書き障害児に おける実験的漢字書字訓練. 音声言語医学, 46：10-15, 2005.

8）川㟝聡大, 宇野 彰: 発達性読み書き障害児 1 例の漢字書 字訓練. 小肾の精神と神経, 45:177-181, 2005.

9）宇野 彰, 春原則子, 金子真人:小学生の読み書きスクリー ニング検査, インテルナ出版, 東京, 2006.

10）大石敬子:読み障害児 3 例における読みの障害機構の検討. LD (学習障害) 一研究と実践一, 6(1)：31-44， 1997.

11）大石敬子, 斉藤佐和子 : 言語発達障害における音韻の問題 一読み書き障害の場合一. 音声言語医学, 40:378-387, 1999.

12）田中裕美子, 兵頭明和, 大石敬子, 他：読み書きの習得や 障害と音韻処理能力との関係についての検討. LD 研究, 15(3): 319-329, 2006.

13）宇野 彰, 金子真人, 春原則子, 他：発達性読み書き障害 一神経心理学的および認知心理学的分析一. 失語症研究, 22(2) : 130-136, 2002.

14）宇野 彰, 春原則子, 金子真人, 他：発達性 dyslexia の 認知障害構造一音韻障害単独説で日本語話者の発達性 dyslexia を説明可能なのか? 一. 音声言語医学, 48：105111, 2007.

15) Pugh KR, Mencl WE, Jenner AR, et al: Neurobiological studies of reading and reading disability. Journal of Communication Disorders, 34: 479-492, 2001.

16) Roeltgen DP and Heilman KM: Lexical agraphia. Further support for the two-system hypothesis of linguistic agraphia. Brain, 107: 811-827, 1984.

17) Richards T, Berninger V, Winn W, et al: Functional MRI activation in children with and without dyslexia during pseudoword aural repeat and visual decode: before and after treatment. Neuropsychology. 21 (6): 732-741, 2007.

18) Church JA, Caolson RS, Lugar HM, et al: A developmental fMRI study of reading and repetition reveals changes in phonological and visual mechanisms over age. Cereb Cortex, 18(9): 2054-2065, 2008.

19) Baddeley A and Wilson B: When implicit learning fails: Amnesia and the problem of error elimination. Neuropsychologia, 32: 53-68, 1994.

別刷請求先：=700-8558 岡山市北区鹿田町 2-5-1 岡山大学病院耳鼻咽喉科言語聴覚外来 藤吉昭江 